\title{
MICROBIOLOGICAL MONITORING OF CLEAN ROOMS IN DEVELOPMENT OF VACCINES
}

\author{
Carla Lílian de Agostini Utescher ${ }^{1 *}$; Marcia Regina Franzolin²; Luiz Rachid Trabulsi² (in memoriam); \\ Valderez Gambale ${ }^{3}$
}

${ }^{1}$ Seção de Controle de Qualidade, Instituto Butantan, São Paulo, SP, Brasil; ${ }^{2}$ Laboratório de Bacteriologia, Instituto Butantan, São Paulo, SP, Brasil; ${ }^{3}$ Laboratório de Micologia Médica, Departamento de Microbiologia, Instituto de Ciências Biomédicas, Universidade de São Paulo, São Paulo, SP, Brasil

Submitted: August 24, 2006; Returned to authors for corrections: July 05, 2007; Approved: September 21, 2007.

\begin{abstract}
The aim of the present work was to evaluate an environmental monitoring program for clean rooms, or classified environments, involved in the filling and quality control of biological products produced by Butantan Institute, São Paulo, Brazil. This monitoring established the quantification, characterization and seasonality of the microorganisms in air and operators and, moreover, determined the alert and action limits. The total detectable microbial number showed some contrasts in installed air purification systems and in the operational impact on adopted procedures. The typical microbial population consisted of Staphylococcus sp, Micrococcus $s p$, Bacillus sp and Penicillium sp. The highest microorganism concentration occurred during summer and springtime. The established internal alert and action limits supported the operational procedures. Therefore, the environmental monitoring program is recommended for other laboratories involved in the production of vaccines, hyperimmune sera and biopharmaceuticals.
\end{abstract}

Key words: environmental control, viable particles, clean rooms, alert and action limits

\section{INTRODUCTION}

The history of Butantan Institute ${ }^{1}$ intermingles with that of public health in Brazil, aiming to assure quality of vaccines, hyperimmune sera and biopharmaceuticals. Butantan Institute performs operational procedures in classified areas according to international regulations such as the International Standards Organization (ISO) (14) and Brazilian National Agency for Sanitary Vigilance (ANVISA) $(9,10)$. In compliance with these guidelines, we have established defined limits regarding the concentration of viable and non-viable particles in suspension. Therefore, Butantan's production currently follows Good Manufacturing Practices (GMP) (13).

In these environments, aseptic procedures are performed, avoiding environmental air contamination throughout complex filter systems, which is composed of thick (G3), and thin filters (F3) and an air terminal unit consisting of high efficiency particulate air (HEPA) filters (4-7). According to ISO regulations, not only the purity class denomination must be evaluated but also the occupational condition of the area. This condition can be as-built, at-rest and dynamic. The global market induces companies' adaptations to international requirements in their production concerning environmental control $(13,17,24)$.

Passive and active air sampling can provide air evaluation for viable particles. In passive air sampling, the environment is monitored by determining the number of microorganisms that settle a culture plate by gravity $(15,18,24)$. In active air sampling, we can quantify microbes by air sample volume.

Humans are considered the main source of contamination in classified areas due to constant endogenous emissions, and the operator who carries out aseptic procedures must be continuously observed and evaluated and must be aware of conduct procedure (15).

*Corresponding Author. Mailing address: Instituto Butantan, Serviço de Controle de Qualidade. Av. Vital Brazil, 1500, Butantã. 05503-900, São Paulo, SP, Brasil. Tel.: (+5511) 3726-7222, Ext. 2154. Fax: (+5511) 3726-3816. E-mail: utescher@butantan.gov.br

1. Founded in 1901. 
Microbiological monitoring of an environment involves microbiological air quality evaluations on operators, the inside of the laboratories and surfaces. Such a program controls the viable microbial load (bioburden), and this monitoring provides data about the air system efficiency in operational procedures.

Alert and internal action at specific microbiological levels can be determined through frequent monitoring of the environment and operators. Therefore, deviations from normal conditions can be detected, allowing corrective procedures before product quality is affected.

The purpose of this work was to introduce an environmental monitoring program for clean rooms or classified environments, designated for the filling and quality control of biological products produced by Butantan Institute.

\section{MATERIALS AND METHODS}

\section{Chosen areas}

The following areas were selected to be microbiologically monitored at-rest and during dynamic operations, where such areas were susceptible to product contamination risk and to false results in sterility tests. The Filling Section consists of a multi dose vaccine room for diphtheria and tetanus vaccine (dT, DT vaccines), diphtheria, tetanus and pertussis recombinant vaccine (DTP), and hepatitis B vaccine; the places where the samples were collected were the laminar flow hood, bench, dressing room and pass-through (at-rest), and the laminar flow module and bench during starting and ending procedures. Blending Section is a formulation area; the sites where sampling was performed were the laminar flow module, right and left room, dressing room and passthrough (at-rest), and for dynamic, the laminar flow module and bench. Microbiological Control Section handles sterility testing; places where samples were obtained were the laminar flow hood and bench test room, dressing room, room bench and pass-through during the ending procedures (dynamic). Weekly samples were obtained in different places, from May, 2002 to April, 2003.

\section{Microbiological methods}

One thousand liters of air sampling were obtained by MAir T sampler (Millipore) through the active sampling method Split to Agar (24). The plates containing Bacto tryptic soy culture medium (Millipore) were incubated for $48 \mathrm{~h}$ at $30^{\circ} \mathrm{C}$ $35^{\circ} \mathrm{C}$ and then for $72 \mathrm{~h}$ at $20^{\circ} \mathrm{C}-25^{\circ} \mathrm{C}$. After incubation, the colonies were counted and recorded in specific protocols. The bacteria were identified by methods described elsewhere (16), and fungal genus identification was according to established techniques $(1,2)$.

The subjects (operators), who had gloved hands during procedures, were monitored by gloved fingerprint in Petri plates containing tryptic casein soy agar, immediately after the procedures. The plates were incubated for $48 \mathrm{~h}$ at $30^{\circ} \mathrm{C}-35^{\circ} \mathrm{C}$ and then for $72 \mathrm{~h}$ at $20^{\circ} \mathrm{C}-25^{\circ} \mathrm{C}$, after which the grown colonies were counted, recorded and sent for identification of bacteria and fungi as described above.

Limits for internal alert and action procedures for each integral environment (three monitored sections) were determined by statistical analysis (mean and standard deviation), which were expressed in colony forming units (CFU) per $\mathrm{m}^{3}$ of air sample. Due to high variability of CFU for single samplings, the following statements were established: Normal work range, mean CFU obtained was increased by two deviations; Alert limit, mean CFU obtained was increased by only one deviation; Action limit, values over the normal range.

\section{RESULTS}

The genera and the total bacterial and fungal colony forming units $\left(\mathrm{CFU} / \mathrm{m}^{3}\right)$ isolated during occupational levels at-rest and dynamic in different environments can be found in Table 1 . The microbial population detected in the air consisted mainly of bacteria from the genera Staphylococcus sp, Micrococcus sp and Bacillus sp, and filamentous fungi from the genus Penicillium $s p$, along with six other fungal genera (Table 1). As we looked into performed operations, there was an increase in microbial contamination as can be observed in the results obtained at the end versus the start of the operational procedure.

Several fungal genera were isolated in the Filling Section during the occupational level at-rest. Concerning the occupational level at-rest, the total number of $\mathrm{CFU} / \mathrm{m}^{3}$ in the Filling Section was 350, in the blending area 218, and in the Microbiological Control Section 780. Yet, the numbers at dynamic operations were respectively: total number of $\mathrm{UFC} / \mathrm{m}^{3}$ at filling area 310, Blending Area 1,954, and, finally, at Microbiological Control Section 1,769.

In class A environment laminar flow hoods, we detected low levels of microbes of the genera Staphylococcus sp, Micrococcus $s p$, Bacillus sp, and Penicillium sp, while other filamentous fungi from the genera Cladosporium sp, Aspergillum sp, Scopulariopsis sp, Fusarium sp, Alternaria sp, and Mycelia sterilia were found only in class D environments (dressing rooms).

The highest level of contamination occurred in the dressing room antechamber. The laminar flow module was free of contamination or had a very low level. Internal alert and action limits for each monitored environment are indicated in Table 2.

Microbial seasonality was evaluated in different environments at-rest and dynamic. Fig. 1A and 1B indicate the total values of $\mathrm{CFU} / \mathrm{m}^{3}$ detected in different seasons: spring (from October to December), summer (from January to March), autumn (from April to June) and winter (from July to

2. In the South Temperate Zone, the seasons are reversed. 
Table 1. Total CFU $/ \mathrm{m}^{3}$ for all detected bacteria and fungi for the three monitored areas.

\begin{tabular}{|c|c|c|c|c|c|c|}
\hline \multirow{2}{*}{ Microbial genus } & \multicolumn{2}{|c|}{ Filling Section } & \multicolumn{2}{|c|}{ Blending Section } & \multicolumn{2}{|c|}{ Microbiological Control } \\
\hline & $\mathrm{A}(\mathrm{n}=50)$ & $B(n=149)$ & $A(n=43)$ & $B(n=72)$ & $\mathrm{A}(\mathrm{n}=51)$ & $B(n=155)$ \\
\hline Staphylococcus sp & 134 & 247 & 170 & 1.063 & 536 & 1.388 \\
\hline Micrococcus sp & 75 & 40 & 43 & 414 & 127 & 207 \\
\hline Bacillus sp & 3 & 15 & 5 & 115 & 18 & 148 \\
\hline Total bacteria & 212 & 302 & 218 & 1,592 & 681 & 1.743 \\
\hline Penicillium sp & 114 & 1 & Absent & 2 & 27 & 26 \\
\hline Cladosporium sp & 9 & 3 & Absent & Absent & Absent & Absent \\
\hline Aspergillus sp & 5 & 3 & Absent & Absent & Absent & Absent \\
\hline Scopulariopsis sp & 1 & Absent & Absent & Absent & Absent & Absent \\
\hline Fusarium $\mathrm{sp}$ & 3 & 1 & Absent & Absent & Absent & Absent \\
\hline Alternaria sp & 5 & Absent & Absent & Absent & Absent & Absent \\
\hline Mycela sterilia & 1 & Absent & Absent & Absent & Absent & Absent \\
\hline Total fungi & 138 & 8 & Absent & 2 & 27 & 26 \\
\hline Total & 350 & 310 & 218 & 1.594 & 708 & 1.769 \\
\hline
\end{tabular}

A - occupational condition "at-rest”; B - occupational condition "dynamic"; n - number of samples.

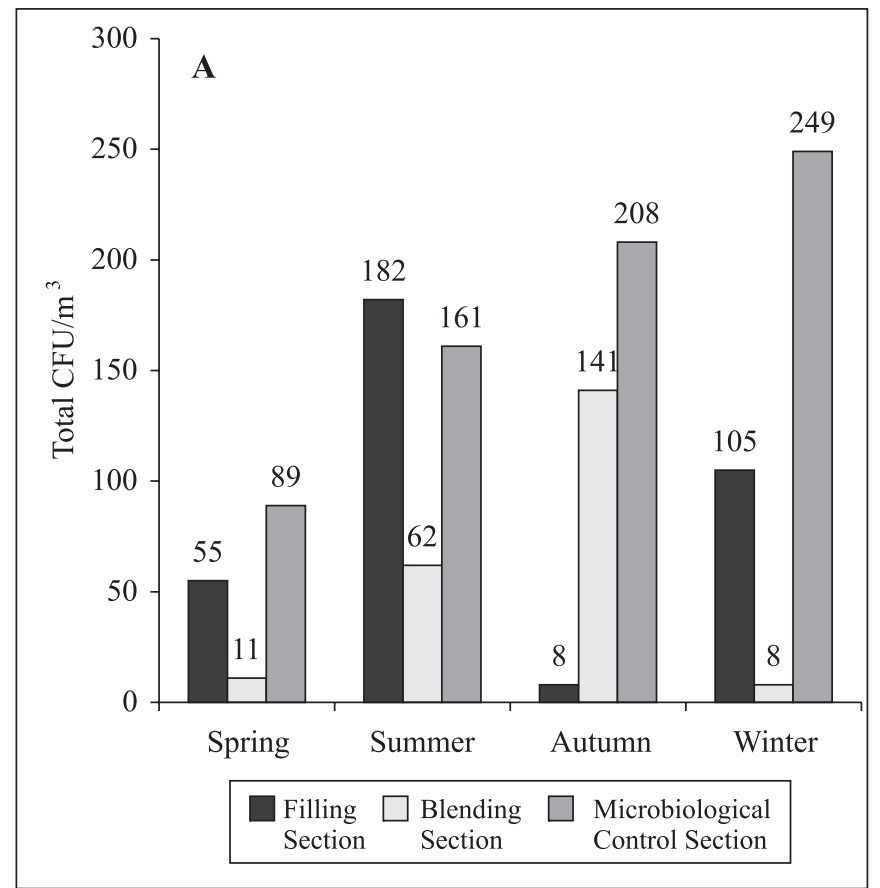

Figure 1A. Isolated microorganisms (total CFU) in the occupational condition "at-rest", at Filling Section, Blending Section and Microbiological Control Section, from May, 2002 to April, 2003.

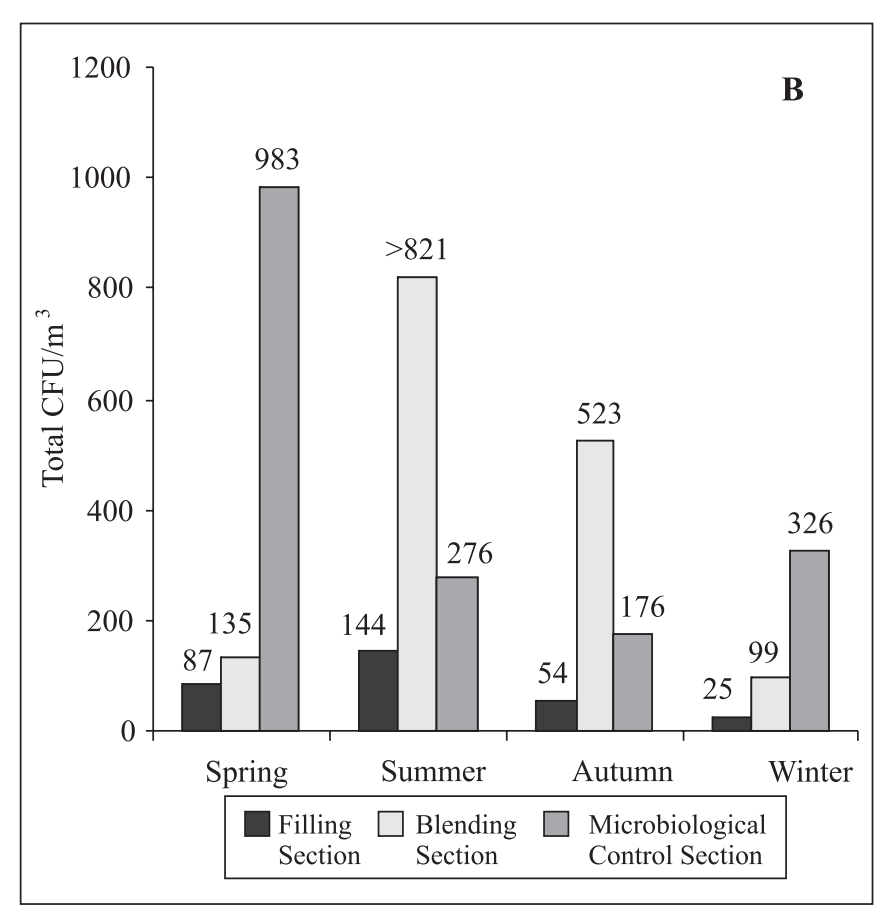

Figure 1B. Isolated microorganisms (total CFU) in the occupational condition "dynamic", at Filling Section, Blending Section and Microbiological Control Section, from May, 2002 to April, 2003. 
Table 2. Normal working range and internal alert and action limits $\left(\mathrm{CFU} / \mathrm{m}^{3}\right)$, for each monitored area.

\begin{tabular}{|c|c|c|c|}
\hline Environment & Normal working range & Alert limit & Action limit \\
\hline \multicolumn{4}{|l|}{ Filling Section - at-rest } \\
\hline Laminar flow module (Class A) & 0 & 0 & 0 \\
\hline Bench (Class C) & 0 & 0 & 0 \\
\hline Pass-through (Class C) & $0-0.44$ & 0.33 & $>0.44$ \\
\hline Dressing-room (Class D) & $0-2.18$ & $0-0.44$ & $>2.18$ \\
\hline Exiting dressing room (Class D) & $0-1.01$ & 0.57 & $>1.01$ \\
\hline Dressing room hall & $0-25.33$ & 15.56 & $>25.33$ \\
\hline \multicolumn{4}{|l|}{ Filling Section - dynamic } \\
\hline Laminar flow module - procedure starting & $0-0.47$ & 0.25 & $>0.47$ \\
\hline Laminar flow module - procedure ending & $0-0.48$ & 0.26 & $>0.48$ \\
\hline Bench - procedure starting & $0-1.90$ & 1.11 & $>1.90$ \\
\hline Procedure ending & $0-3.82$ & 8.13 & $>13.82$ \\
\hline \multicolumn{4}{|l|}{ Blending Section - at-rest } \\
\hline Laminar flow module (Class A) & 0 & 0 & 0 \\
\hline Bench (Class C) & $0-9.18$ & 5.3 & $>9.18$ \\
\hline Pass-through (Class C) & $0-4.45$ & 2.64 & $>4.45$ \\
\hline Dressing room (Class C) & $0-6.12$ & 3.60 & $>6.12$ \\
\hline Exiting dressing room (Class C) & $0-15.46$ & 8.84 & $>15.46$ \\
\hline \multicolumn{4}{|l|}{ Blending Section-dynamic } \\
\hline Laminar flow module - procedure starting & $0-0.61$ & 0.33 & $>0.61$ \\
\hline Procedure ending & $0-0.62$ & 0.45 & $>0.62$ \\
\hline Bench - procedure starting & $0-55.72$ & 33.50 & $>55.72$ \\
\hline Procedure ending & $0-47.27$ & 29.49 & $>47.27$ \\
\hline \multicolumn{4}{|c|}{ Microbiological Control Section - at-rest } \\
\hline Laminar flow hood (Class A) & 0 & 0 & 0 \\
\hline $\operatorname{Bench}($ Class C) & $0-8.28$ & 5.23 & $>9.28$ \\
\hline Pass-through (Class D) & $0-6.19$ & 3.69 & $>6.19$ \\
\hline Entrance dressing room (Class C) & $0-46.45$ & 27.67 & $>46.45$ \\
\hline Dressing room (Class D) & $0-8.87$ & 5.66 & $>8.87$ \\
\hline Exiting dressing room (Class D) & $0-21.63$ & 13.12 & $>21.63$ \\
\hline \multicolumn{4}{|c|}{ Microbiological Control Section - dynamic } \\
\hline Laminar flow module - procedure ending & 0 & 0 & 0 \\
\hline Bench - procedure ending & $0-55.50$ & 33.17 & $>53.50$ \\
\hline Pass-through & $0-7.16$ & 4.29 & $>7.16$ \\
\hline
\end{tabular}

September)*3. The largest concentration of microorganisms occurred during the summer and spring.

Operators' gloved hands evaluated after operational procedures in each monitored environment displayed mainly bacteria from the genera Staphylococcus sp, Bacillus sp, Micrococcus $s p$ and the filamentous fungus Penicillium $s p$.
The majority of samplings on the operators' hands resulted in the lack of CFU or the presence of only one CFU. Other microorganisms such as Staphylococcus aureus, Pseudomonas fluorescens, Pseudomonas putida, Alcaligens xylosidans were detected in sampling from distinct operators (Table 3). 
Utescher, C.L.A. et al.

Table 3. Collection number grouped according to detected CFU $/ \mathrm{m}^{3}$ and microbial genera on Operator's gloved hands for each monitored area.

\begin{tabular}{|c|c|c|c|c|c|}
\hline \multirow{2}{*}{ Area } & \multicolumn{4}{|c|}{ Collection number } & \multirow{2}{*}{ Total } \\
\hline & $0 \mathrm{CFU}$ & $1 \mathrm{CFU}$ & $2 \mathrm{CFU}$ & $\geq 3$ UFC & \\
\hline Filling Section & 129 & 18 & 03 & 12 & 162 \\
\hline Blending Section & 153 & 05 & 01 & 01 & 160 \\
\hline $\begin{array}{l}\text { Microbiological } \\
\text { Control Section }\end{array}$ & 167 & 23 & 09 & 10 & 209 \\
\hline \multirow{2}{*}{ Area } & \multicolumn{5}{|c|}{ Microbial Genera (CFU - \%) } \\
\hline & Staphylococcus sp & Bacillus sp & Micrococcus sp & Pseudomonas $s p$ & Penicillium $s p$ \\
\hline Filling Section & $\begin{array}{l}111 \mathrm{CFU} \\
(52.11 \%)\end{array}$ & $\begin{array}{l}75 \mathrm{CFU} \\
(35.21 \%)\end{array}$ & $\begin{array}{l}23 \mathrm{CFU} \\
(10.8 \%)\end{array}$ & $\begin{array}{l}\text { 4UFC } \\
(1.88 \%)\end{array}$ & 0 \\
\hline Blending Section & $\begin{array}{l}52 \mathrm{CFU} \\
(49.06 \%)\end{array}$ & $\begin{array}{l}14 \mathrm{CFU} \\
(13.21 \%)\end{array}$ & $\begin{array}{c}\text { 14CFU } \\
(13.21 \%)\end{array}$ & 0 & $\begin{array}{l}26 \mathrm{UFC} \\
(24.53 \%)\end{array}$ \\
\hline $\begin{array}{l}\text { Microbiological } \\
\text { Control Section }\end{array}$ & $\begin{array}{l}\text { 41CFU } \\
(33.61 \%)\end{array}$ & $\begin{array}{l}52 \mathrm{CFU} \\
(42.62 \%)\end{array}$ & $\begin{array}{l}25 \mathrm{CFU} \\
(20.50 \%)\end{array}$ & $\begin{array}{l}2 \mathrm{UFC} \\
(1.64 \%)\end{array}$ & $\begin{array}{l}2 \mathrm{UFC} \\
(1.64 \%)\end{array}$ \\
\hline
\end{tabular}

\section{DISCUSSION}

Environmental monitoring programs, although developed in other institutions, have limited detailed published results. Therefore, it is difficult to make a comparison between the data from this study and those of others. Besides, in Brazil, only three large institutions are dedicated to immunobiologicals production, Butantan Institute (São Paulo), Oswaldo Cruz Foundation (FIOCRUZ, Rio de Janeiro) and Paraná Technology Institute (TECPAR, Paraná). These institutes have only recently started the implementation of this program (SBCC, 2002) (19).

The total viable microorganisms detected in the occupational condition at-rest revealed some existing differences in the air purification systems. The multi-dose vaccine filling room had $350 \mathrm{CFU}$, the blending room $218 \mathrm{CFU}$, and the sterility test room I, $708 \mathrm{CFU}$. These results suggest a lower efficiency in the air system, since the cleaning procedures are the same for each evaluated area.

Total viable microorganisms detected in the occupational condition dynamic reflected the impact of the operational procedures. Comparing both occupational conditions, for the Filling Section, there was no difference in its microbiological characteristics: CFU number for at-rest condition was $12.9 \%$, lower than for dynamic condition. On the other hand, for the Blending Section and for Microbiological Control Section, there were greater differences between observed CFU in the two conditions. Blending Section had an increase of $631.19 \%$ for the dynamic operational condition, probably due to the intense circulation in the area in manipulating large equipment such as tanks used in vaccine formulation. The Microbiological Section showed a difference of $149.85 \%$ between the operational conditions. This value may indicate that the air purification system is not able to achieve an efficient auto-regeneration, since the procedures performed were with small equipment for testing sterility. Comparing the results before and after procedures, in the Filling Section, there was no effect on the room microbiological characteristics when the operational procedures were performed under the laminar flow module, but when they were performed on the bench there was an increase in CFU number. This finding indicates that the operator's work impacted directly the results.

At the Blending Section, both operational procedures under the laminar flow module or on the bench did not show differences in microbial characteristics of the environment, which indicates that the operator's work did not affect the results.

The characteristic microbial population identified in these monitored areas was composed of the bacteria Staphylococcus sp, Micrococcus sp, Bacillus sp, and the fungus Penicillium $\mathrm{sp}$, with a predominance of Staphylococcus sp in all areas. These three bacterial genera have a ubiquitous distribution. They have been isolated from the environment or on human skin and mucous membranes. Members from the genus Staphylococcus $s p$ can cause a large variety of illnesses, such as folliculitis and abscess, whereas the $S$. aureus is the most important pathogen from this genus (26). Fungi from the genus Penicillium $s p$, Deuteromycetes, commonly found in soil, are the main components of atmospheric microbiota $(1,2)$. Therefore, the presence of these microorganisms in classified areas is due 
to a constant endogenous release from the operators, which indicates that they are one of the most important causes of environmental contamination.

The low incidence of contaminants in Class A environments is characterized by microorganisms from Staphylococcus $s p$ and Bacillus sp genera, while in Class C and Class D, Staphylococcus sp, Micrococcus sp, Bacillus sp and Penicillium sp were isolated. Other filamentous fungi such as Cladosporium sp, Aspergillus sp, Scopulariopsis sp, Fusarium sp, Alternaria $\mathrm{sp}$ and Mycelia sterilia were found in low concentrations and predominantly in class D environments.

There are no recommendations about maximum number of viable microorganisms per cubic meter for the at-rest operational condition in the current Brazilian national guidelines. In Class A environments there were no contaminants. The working range was from 0 to $9.18 \mathrm{CFU}$ in Class C. Class D environment, consisting of entrance dressing-rooms, showed a range from 0 to $46.45 \mathrm{CFU}$, dressing-room from 0 to $8.87 \mathrm{CFU}$, and exiting dressing-room from 0 to $21.63 \mathrm{CFU}$. The values reflected the operator's flow. A gradual reduction was observed from the dressing-room to the room with laminar flow, where critical procedures were performed.

Dynamic operational procedures, being the most critical moment of the operation, had for Class A environments, a normal range from 0 to $0.62 \mathrm{CFU}$ and Class $\mathrm{C}$ environments, from 0 to 53.50 CFU. These results were below the maximum recommended in the guidelines $(9,10)$ for each environment. Furthermore, these values demonstrate that there was no impact of environmental contamination on the final product quality, since after the sterility test the products were approved.

Seasonality and microbial population distribution could only be evaluated in the dynamic operational condition, because the areas have stable and controlled conditions and because they are not influenced by external conditions such as humidity and temperature. The presence of different operators and the constant release of endogenous contaminants led to an increase in CFU in the three evaluated areas after October. The highest contamination was observed in spring and summer and the lowest during the autumn and winter periods.

Microbial load at the operator's gloved hands reflected the same microbial genera as those from the air contamination, indicating the operator as the main source of contamination . The predominance of Staphylococcus sp reveals that the operators, even dressing in complete uniforms, need an extensive training in aseptic techniques.

The results obtained show that the operational procedures can affect the microbiological characteristics of the areas evaluated, which are related to the kind of activity and the air system efficiency. Furthermore, the working conditions at the Blending Section, Filling Section and Microbiological Control Section were satisfactory, assuring high product quality and can be recommended for other producers of immunobiologicals and biopharmaceuticals. The normal working ranges and internal alert and action limits allow deviations to be controlled before product quality is affected.

\section{RESUMO}

\section{Monitoramento Microbiológico de Áreas Classificadas em Desenvolvimento de Vacinas}

O presente trabalho teve por objetivo avaliar um programa de monitoramento microbiológico ambiental para áreas limpas, ou ambientes classificados, envolvidas na produção, envasamento e controle dos imunobiológicos produzidos pelo Instituto Butantan. Este monitoramento permitiu a quantificação, a caracterização e a sazonalidade da população microbiana presente no ar e nos operadores, e a determinação dos limites de alerta e ação. O número total de bactérias detectáveis revelou diferenças nos sistemas de purificação de ar instalados e o impacto operacional ocasionado pelos procedimentos realizados. A população microbiana característica foi composta por bactérias dos gêneros Staphylococcus sp, Micrococcus $s p$, Bacillus sp e por fungos filamentosos do gênero Penicillium $s p$. A maior concentração de microrganismos ocorreu nos períodos de verão e primavera. Os limites internos de alerta e ação estabelecidos asseguram os procedimentos operacionais, recomendando o monitoramento microbiológico ambiental a outros laboratórios envolvidos na produção de vacinas, soros hiperimunes e imunobiológicos.

Palavras-chave: controle ambiental, partículas viáveis, áreas limpas, limites de alerta e ação

\section{REFERENCES}

1. Ainsworth, G.C.; Sparrow, F.K.; Sussman, A.S. The Fungi. An advanced Treatise. A taxonomic review with key: Ascomycetes and Fungi Imperfect. Vol IVA. Academic Press, New York, 1973, 621 pp.

2. Arx, J.A. von The Genera of Fungi Sporulating in Pure Culture. $3^{\text {rd }}$ ed., J. Cramer, Vaduz, Germany, 1981, 215 pp.

3. Brasil. ABNT. ISO/IEC. Associação Brasileira de Normas Técnicas. Diretiva Parte 3: Redação e Apresentação de Normas Brasileiras, 1995.

4. Brasil. ABNT. Norma Brasileira NBR 13700. Áreas Limpas Classificação e Controle de Contaminação. Associação Brasileira de Normas Técnicas, Rio de Janeiro, junho, 1996.

5. Brasil. SBCC-RN-002-95. Classificação e Controle de Contaminação de Áreas Limpas. Texto enviado para ABTN como Projeto de Norma $n^{\circ}$ 01: 604.02001, dezembro, 1995.

6. Brasil. SBCC-RN-003-95. Testes de Velocidade, Vazão e Uniformidade do Fluxo em Áreas Limpas.

7. Brasil. SBCC-RN-005-97. Testes em Áreas Limpas, dezembro, 1997.

8. Brasil. Instituto Nacional de Controle de Qualidade em Saúde (INCQS). Manual de Controle de Qualidade de Produtos Imunobiológicos, 1984

9. Brasil. RDC 134. Agência Nacional de Vigilância Sanitária (ANVISA), 13 de julho de 2001.

10. Brasil. RDC 210. Agência Nacional de Vigilância Sanitária (ANVISA), 04 de agosto de 2003. 
11. Cannoll, C.; Van Pala, M.; Voll Herbst, L. Microbiological Validation of a New Manufacturing Complex for an Injectable Biological Product. J. Parenter Sci of Technol, 46, 107-10, 1992.

12. Cooper, D.W. Cleaning Asseptic Fill Areas. Pharm. Technol., 20, 52-60, 1997.

13. Food and Drug Administration. FDA. Food and Drug Administration Guideline on Sterility Drug Products Produced by Aseptic Processing, June, 1987.

14. Genebra. International Organization for Standardization - ISO. International Norm ISO 9000-1: 1994: Quality management and quality assurance standards. Part 1: Guidelines for selection and use. Completed by ISO 9001: 1994: Quality systems - Model for quality assurance in design, development, production, installation and servicing; ISO 9002: 1994: Quality systems - Model for quality assurance in production, installation and servicing; ISO 9003: 1994: Quality systems - Model for quality assurance in final inspection and test; ISO 9004-1: 1994: Quality management and quality system elements - Part 1: Guidelines

15. Institute of Environmental Sciences. IES-RP-CC023.1. Microorganisms in clean rooms, 1998.

16. Koneman, E.W.; Allen, S.D.; Janda, W.M.; Schreckenberger, P.C.; Winn Jr., W.C. Diagnostic Microbiological. Color atlas and textbook. $5^{\mathrm{a}}$ ed. Lippincott, Philadelphia, Pennsylvania, 1997, 1395p.
17. Luxemburg. Office for Official Publications of the European Communities Manufacture of Sterile Medicinal Products, Annex 1. Rules and guidance for pharmaceutical manufactures and distributors, July, 1996.

18. Luxemburg. Office for Official Publications of the European Communities. The rules governing medicinal products in the European Union. Vol. 4: Good manufacturing practices - Medicinal products for human and veterinary use, 1998.

19. Seabra, M. Salas limpas na produção de vacinas. Rev. da Soc. Bras. de Controle de Contam. (SBCC), 4-6, 2002.

20. Technical Report. Fundamentals of a Microbiological Environmental Monitoring Program, $n^{\circ} 13$ vol. 44 (51), 1990.

21. Tetzlaff, R.F. Clean Room Environmental Monitoring. J. of Parenter Sci. \& Technol., 46, 206-14, 1992.

22. United States. US Federal Standard 209 E: Airborne Particulate Cleanliness classes for clean rooms and clean zones. September 11, 1992.

23. United States. The United States Pharmacopeia. Microbiological Evaluation of Clean Rooms and Other Controlled Environments, volume 21, Number 2 In: Convention Pharmacopeia Forum <1116>.

24. United States. The United States Pharmacopeia USP 24, Microbiological Evaluation of Clean Rooms and Other Controlled Environments <1116>. 